\title{
Ultraphytoplankton in the eastern Mediterranean Sea: towards deriving phytoplankton biomass from flow cytometric measurements of abundance, fluorescence and light scatter
}

\author{
W. K. W. Li ${ }^{1}$, T. Zohary ${ }^{2}$, Y. Z. Yacobi ${ }^{2}$, A. M. Wood ${ }^{3}$ \\ ${ }^{1}$ Biological Oceanography Division, Bedford Institute of Oceanography, Dartmouth, Nova Scotia, Canada B2Y 4A2 \\ ${ }^{2}$ The Yigal Allon Kinneret Limnological Laboratory, Israel Oceanographic and Limnological Research Ltd, PO Box 345 , \\ Tiberias 14102, Israel \\ ${ }^{3}$ Department of Biology, University of Oregon, Eugene, Oregon 97403, USA
}

\begin{abstract}
Prochlorophytes, cyanobacteria and eukaryotic ultraphytoplankton from the southern Levantine Basin of the eastern Mediterranean Sea were analyzed by flow cytometry to obtain measurements of cell abundance, relative cellular fluorescence and relative cellular light scatter. Assuming that fluorescence is a proxy for chlorophyll and that light scatter is a proxy for cellular carbon, phytoplankton biomass can be expressed as the sum (over all cell groups) of adaptive cellular characteristics (i.e. chorophyll and carbon) weighted by cell abundance. On this basis, much of the carbon appeared attributable to eukaryotic ultraphytoplankton, but chlorophyll was more evenly partitioned such that the contributions from prochlorophytes and cyanobacteria were also significant. The subsurface chlorophyll maximum coincided with the maximum in total fluorescence but not with the maximum abundance of cells nor with the presumed maximum in the carbon biomass of ultraphytoplankton.
\end{abstract}

KEY WORDS: Chlorophyll - Cyanobacteria - Flow cytometry - Mediterranean Prochlorophytes · Ultraphytoplankton

\section{INTRODUCTION}

The concentration of particulate chlorophyll a (chl a) is an important and easily measured variable. It has long served as an index of phytoplankton biomass and its vital role in biological oceanography is indisputable. $\mathrm{Chl} a$ is a bulk property of seawater. In common with other bulk measurements, chl a gives no indication of the relative contribution from constituents. For example, the same chl a value can be obtained from a sample containing a few large phytoplankton cells and from a sample containing many small cells. Thus, while the bulk measurement of chl a provides a good estimate of the pigment biomass of primary producers, it can mask many important differences that affect ecosystem structure and function. For this reason, as emphasised by Platt (1989) and Yentsch \& Campbell (1991), the recovery of bulk properties from the details of the constituents is a most desirable goal in phytoplankton research.

To this end, we follow Shimada et al. (1993) in comparing bulk measures of chl a with the summed contributions of properties from single cells of the ultraphytoplankton measured by flow cytometry. The study was made on phytoplankton sampled from the southern Levantine Basin of the eastern Mediterranean Sea. The waters in this region are extremely oligotrophic (Berman et al. 1984), and most of the chl a is attributable to cells passing $10 \mu \mathrm{m}$ membrane filters (Y. Z. Yacobi, T. Zohary, N. Kress, A. Hecht, R. D. Robarts, M. Waiser \& W. K. W. Li unpubl.). As expected from observations elsewhere (Li et al. 1992a, b), the ultraphytoplankton here includes prochlorophytes, unicellular cyanobacteria, and various red-fluorescing pico- and nano-phytoplankton (A. M. Wood, J. Neveux, M. Sondergaard \& Y. Z. Yacobi unpubl.; Yacobi et al. 
unpubl.). In the Mediterranean Sea, the microspectrofluorimetric results of Zaika \& Yashin (1984) on abundant 'red luminescing' algae of $0.5 \mu \mathrm{m}$ size preceded the more recent flow cytometric observations of prochlorophytes (Vaulot et al. 1990, Li et al. 1992b, Vaulot \& Partensky 1992).

In this paper, we first formulate the concepts required to derive phytoplankton biomass (in terms of chl $a$ and carbon) from flow cytometric measurements and then indicate the difficulties of achieving this goal We follow by suggesting 2 interim approaches for examining the data at hand. Finally, we present our results for both approaches. In these waters, we conclude that the observed depth distribution of bulk chl a can be faithfully matched by joint considerations of cell abundance and pigment content of the ultraphytoplankton. Furthermore, we suggest that the subsurface chlorophyll maximum did not correspond with the maximum abundance of cells nor with the maximum in the carbon biomass of ultraphytoplankton.

\section{CONCEPTUAL OUTLINE}

Proceeding from the general ideas of Yentsch \& Campbell (1991), we express the concentration of chl a $\left(\mu \mathrm{g}^{-1}\right)$ at depth $z$ as follows:

$$
\operatorname{chl} a(z)=\sum_{i} n_{1}(z) \cdot f_{i}(z) \cdot \psi_{i}(z)
$$

where $i$ refers to each recognizable group (i.e. prochlorophytes, cyanobacteria, photosynthetic eukaryotes); $n=$ cell concentration (cells $l^{-1}$ ); $f=$ mean cellular fluorescence (relative fluorescence units cell ${ }^{-1}$ ); $\psi=$ chlorophyll content per unit fluorescence [ $\mu \mathrm{g}$ (relative fluorescence unit $)^{-1}$. This is a formal statement of the approach presented by Shimada et al. (1993).

The concept of $\psi$ denotes the use of in vivo fluorescence as a measure of chlorophyll. Unfortunately, $\psi$ is variable, both genotypically and phenotypically (Cullen 1982). Furthermore, the relationship between cellular chlorophyll content and flow cytometric fluorescence may be nonlinear (Sosik et al. 1989). The uncertainty involved in assigning values to $\psi_{i}$ makes it difficult to directly implement Eq. (1).

Likewise, the concentration of phytoplankton carbon (C. $\mu \mathrm{g} \mathrm{l}^{-1}$ ) at depth $z$ can be expressed as follows:

$$
C(z)=\sum_{i} n_{1}(z) \cdot s_{1}(z) \cdot \chi_{i}(z)
$$

where $s=$ mean cellular light-scatter (relative scatter units cell $1^{-1}$ ); $\chi=$ carbon content per unit of scatter [ $\mu \mathrm{g}$ (relative scatter unit) ${ }^{-1}$ ]. As with fluorescence, a parameter $(\chi)$ is needed to denote the use of cellular light scatter as a measure of carbon content. It is commonly accepted that cellular carbon content is directly related to cell volume (Strathmann 1967). Furthermore, strong empirical correlations between cellular light scatter and celi volume have been established using a variety of algae including calcifying strains of coccolithophores (Olson et al. 1989, Chisholm 1992). At the low angles used by the flow cytometer to measure forward scatter, the influences of cell shape and refractive index appear to be minor (Olson et al. 1989). We can therefore expect that flow cytometric light scatter is related (in a non-linear fashion) to cellular carbon; but the uncertainty involved in assigning values to $\chi_{i}$ makes it difficult to directly implement Eq. (2).

To summarize: we have the quantities $n_{i} f_{i}$ and $s_{1}$ from flow cytometry; but not $\psi_{i}$ and $\chi_{1}$. We also have the quantity chl a measured by bulk fluorometry of solvent-extracted pigments. However, we do not have the quantity $C$ which is difficult to estimate (for methods see Eppley et al. 1977) because there is no bulk chemical assay method. In this paper, we approach the problem in 2 ways. In turn, we assume that $\psi_{,}(z)$ is the same for all $i$ at each $z$, and then that $\psi_{i}(z)$ for each $i$ is the same for all $z$.

In the first approach, we make the simplifying assumptions that at a given depth, a single (unknown) value $\Psi(z)$ can be taken to represent all the values of $\psi_{i}(z)$; and that a single (unknown) value $X(z)$ can be taken to represent all the values of $\chi_{i}(z)$.

$$
\begin{aligned}
& \operatorname{chl} a(z)=\Psi(z) \cdot \sum_{i} n_{1}(z) \cdot f_{i}(z) \\
& \operatorname{chl} a(z)=\Psi(z) \cdot F(z) \\
& C(z)=X(z) \cdot \sum_{i} n_{1}(z) \cdot s_{i}(z) \\
& C(z)=X(z) \cdot S(z)
\end{aligned}
$$

where $F$ represents the summation in Eq. (3a) and $S$ represents the summation in Eq. (4a). With this approach, we cannot 'derive' phytoplankton biomass from flow cytometric information; however it is a means of comparing the properties of particular phytoplankton groups with the bulk chlorophyll (see below).

In the second approach, we assume that for each cell group $i$, a single (to be estimated) value of $\psi_{i}^{\prime}$ which is independent of depth can be taken to represent all the values of $\psi_{1}(z)$

$$
\operatorname{chl} a(z)=\sum_{i} n_{i}(z) \cdot f_{i}(z) \cdot \psi_{i}^{\prime}
$$

We use multiple regression analysis to estimate the parameters $\psi^{\prime}$, from Eq. (5). This approach, like the first, does not 'derive' chl a from flow cytometric information but is useful in characterizing the group composition of bulk chlorophyll (see below). Gieskes \& Kraay (1983) and Gieskes et al. (1988) presented this regression approach as a means to infer the contribu- 
tion to total chlorophyll from various algal taxa determined by high-performance liquid chromatography (HPLC) analysis of pigments.

\section{METHODS}

The locations at which samples were collected for flow cytometric analysis are shown in Fig. 1. The stations labelled by alphabetical letters were sampled from the Turkish vessel 'Bilim'; those labelled by numerals were sampled from the Israeli vessel 'Shikmona'. Details of the cruise programme, methods of sample procurement and fluorometric assay of acetone-extracted chl a appear elsewhere (Yacobi et al. unpubl.). Samples for flow cytometric analysis were preserved by the method of Vaulot et al. (1989) and analyzed using the FACSort instrument (Becton Dickinson). Recently, new information indicates that paraformaldehyde may be the preservative of choice for picoplankton (Landry et al. 1993, Monger \& Landry 1993, Sieracki \& Cucci 1993) but we were unaware of this when we used glutaraldehyde according to Vaulot et al. (1989). Measurements of chlorophyll fluorescence and light scatter were recorded in relative units from 1 to $10^{4}$. Using criteria described in previous studies by others (Olson et al. 1990a, Vaulot et al. 1990, Veldhuis et al. 1993) and ourselves (Li \& Wood 1988, Li et al. 1992a, b), we classified the fluorescing particles into 3 groups: prochlorophytes, cyanobacteria and eukaryotic ultraphytoplankton. Cell abundance, mean fluorescence per cell, and mean light scatter per cell were extracted from listmode data using LYSYS II software (Becton Dickinson).

\section{RESULTS}

\section{Regional variation of ultraphytoplankton}

Generally, the depth distribution of ultraphytoplankton cells was similar throughout the study area (Fig. 2). Prochlorophytes ranged from $10^{3}$ to $10^{4}$ cells $\mathrm{ml}^{-1}$ at the surface, and attained a subsurface peak between 70 and $100 \mathrm{~m}$ at concentrations from 1 to $4 \times 10^{4}$ cells $\mathrm{ml}^{-1}$. The highest concentrations of both cyanobacteria and eukaryotes were found in the upper zone; ${ }_{i}$ about. $10^{3}$ to $10^{4}$ cyanobacteria $\mathrm{ml}^{-1}$ and about 500 eukaryotes $\mathrm{ml}^{-1}$.

Two stations were exceptional: Stns $12 \& 18$. These were located within an anti-cyclonic eddy immediately southeast of Crete (Yacobi et al. unpubl.). Here, the water column was well-mixed to a great depth and this can be seen in the relatively uniform vertical distribution of all ultraphytoplankton cells down to about $130 \mathrm{~m}$ (Fig. 2).

\section{Profiles of $n_{i}, f_{i}$ and $s_{i}$}

The depth variations of $n_{1}, f_{i}, s_{1}, n_{1} \cdot f_{i}$ and $n_{1} \cdot s_{1}$ are shown in 3 examples. The first (Fig. 3) refers to mean values along a horizontal transect at $33^{\circ} 30^{\prime} \mathrm{N}$ (Stns 72 , $76,77,80$ ). The second was Stn 54 (Fig. 4) where the concentration of bulk chl a at the subsurface peak was double that along the aforementioned horizontal transect. The third was Stn 18 (Fig. 5) inside the eddy where prochlorophytes were much less abundant.

Three significant points emerge from inspection of these profiles. First, the range span for the product $n_{i} \cdot f_{i}$ was generally comparable for each of the 3 groups. For example, along the horizontal transect (Fig. 3), $n_{\text {Prochl }}$ was large and $f_{\text {prochl }}$ was small; conversely $n_{\text {Euk }}$ was small and $f_{\text {Euk }}$ was large. However, the products $n_{\text {Prochl }} \cdot f_{\text {Prochl }}$ and $n_{\text {Euk }} \cdot f_{\text {Euk }}$ were comparable. Second, $n_{\text {Euk }} \cdot s_{\text {Euk }}$ was always much larger than either $n_{\text {Cya }} \cdot s_{\text {Cya }}$ or $n_{\text {Prochl }} \cdot s_{\text {Prochl }}$. That is to say, the much larger degree of light scattering by each eukaryotic cell carried more weight than the large numbers of prokaryotic cells. Third, the vertical variation of the products $\left(n_{i} \cdot f_{i}\right.$ and $n_{1} \cdot s_{1}$ ) could be quite different from the variation of the component factors. For example, along the horizontal transect (Fig. 3), clear subsurface peaks in $n_{i} \cdot f_{i}$ appeared for cyanobacteria and eukaryotes even though no such peaks appeared in the profiles of $n_{\text {, }}$ alone. 


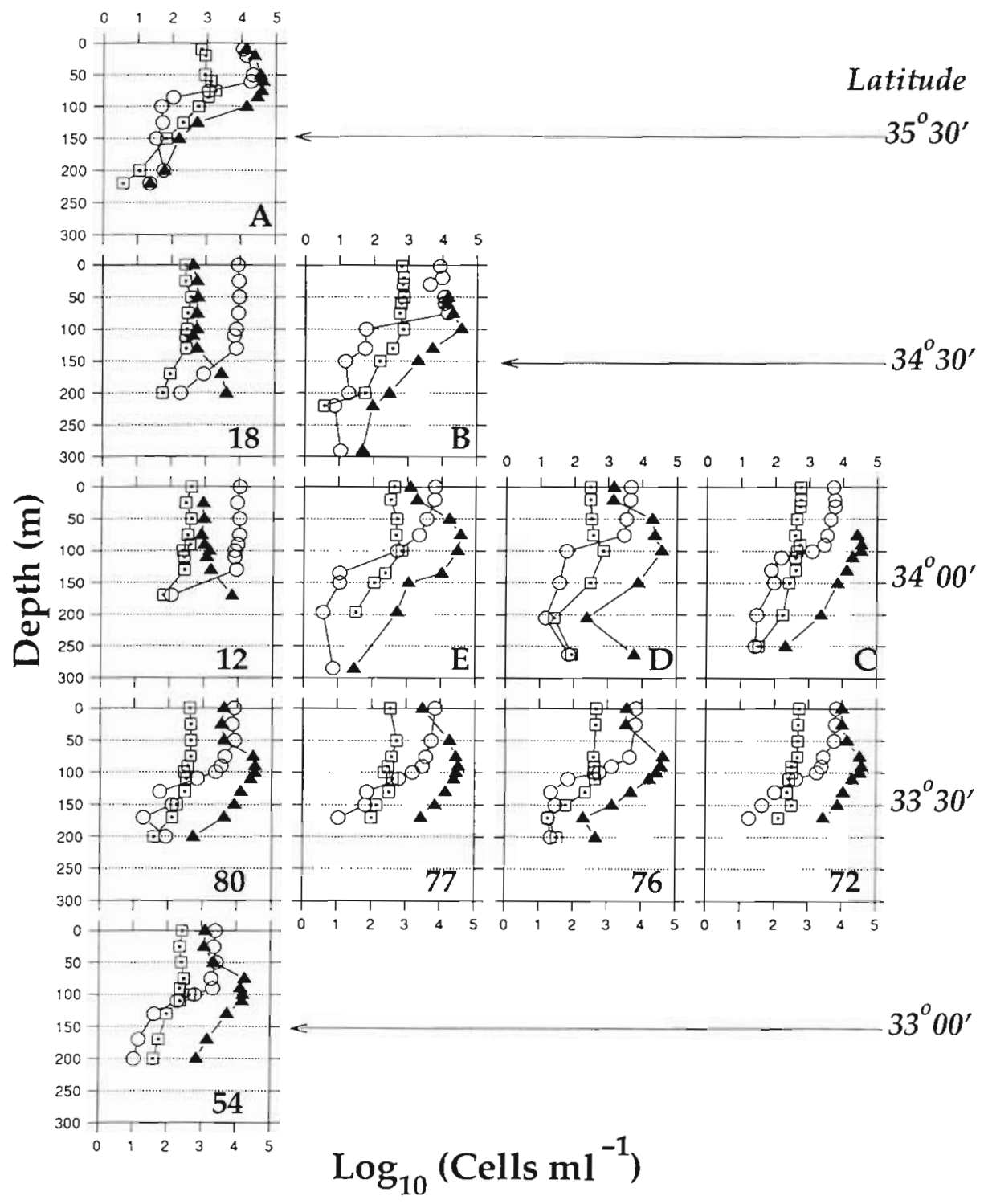

Fig. 2. Vertical distribution of (A) prochlorophytes, (0) cyanobacteria and (ए) eukaryotic ultraphytoplankton at stations indicated in Fig. 1

\section{Profiles of $F$ and $S$}

The summed contribution from each of the 3 ultraphytoplankton groups is expressed as $F$ (Eq. 3a, b) and $S$ (Eq. $4 \mathrm{a}$, b). For each of the 3 examples (Figs. 3, $4 \& 5$ ), the depth variations in $F$ and bulk chl a were closely matched (Fig. 6A, C, E). However, the match between $S$ and chl a was poor (Fig. 6B, D, F). Profiles of $S$ were largely similar to profiles of $n_{\text {Euk }} \cdot s_{\text {Euk }}$ implicating minor contributions from cyanobacteria and prochlorophytes to overall phytoplankton carbon biomass.

\section{Estimating $\psi_{i}^{\prime}$ by regression}

If we assume that $\psi_{2}$ did not vary with depth (which is likely incorrect), then $\psi^{\prime}$, (which is independent of depth) can be estimated for each station by regression using measured values of chl $a(z), n_{j}(z)$ and $f_{i}(z)$ (Eq. 5). The fit of data for individual stations was extremely good $\left(r^{2}>0.97\right.$, Fig. 7) and deteriorated only slightly when all data were pooled $\left(\mathrm{r}^{2}=0.87\right.$, Fig. 7). Using regression-estimated values of $\psi_{1}^{\prime}$, the percentage contribution to chl a from each ultraphytoplankton group at a given depth was calculated as:

$$
\frac{\left[n_{i}(z) \cdot f_{i}(z) \cdot \psi_{i}^{\prime}\right]}{\left[\sum_{1} n_{1}(z) \cdot f_{i}(z) \cdot \psi_{1}^{\prime}\right]} \times 100
$$

This analysis indicates dominance by cyanobacteria above $100 \mathrm{~m}$, dominance by prochlorophytes below $100 \mathrm{~m}$, and significant intermediate contribution from eukaryotes at all depths (Fig. 7). 
Fig. 3. Ultraphytoplankton along the horizontal transect at $33^{\circ} 30^{\prime} \mathrm{N}$ (mean of Stns 72,76 , 77 and 80 ) showing properties for cyanobacteria (top row), prochlorophytes (centre row) and eukaryotic ultraplankton (bottom row) Left column shows cell abundance, $n_{1}\left(\bullet, 10^{3}\right.$ cells $\left.\mathrm{ml}^{-1}\right)$; centre column shows light scatter per cell, $s_{1}(\nabla$, relative scatter units per cell, top $x$-axis label) and light scatter per $\mathrm{ml}, n_{j} \cdot s$ $(\boldsymbol{\nabla}$, relative scatter units per $\mathrm{ml}$, bottom $x$-axis label); right column shows fluorescence per top $x$-axis label) and fluorescence per $\mathrm{ml}$, $n_{i} \cdot f_{l}(\mathbf{E}$, relative fluorescence units per $\mathrm{ml}$, bottom $x$-axis label)

\section{DISCUSSION}

The view of phytoplankton composition presented by flow cytometric analysis is based on cell abundances. In oligotrophic oceanic waters, cytometric signatures are generally dominated by large numbers of prochlorophytes and cyanobacteria. Eukaryotic ultraplankton cell, $f_{i}(\square$, relative fluorescence units per cell
Abundance

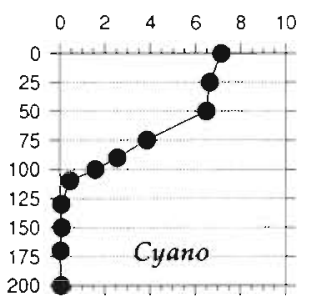

$\begin{array}{lllll}10 & 20 & 30 & 40 & 50\end{array}$
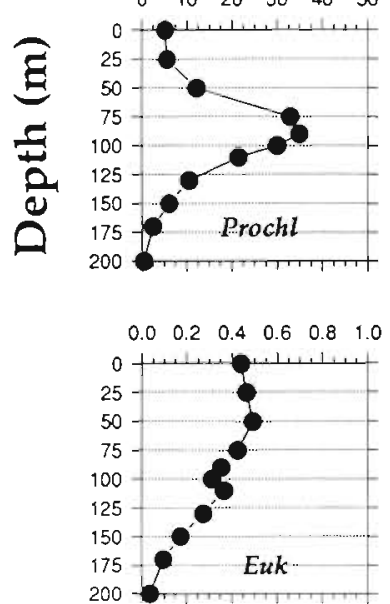

Light Scatter

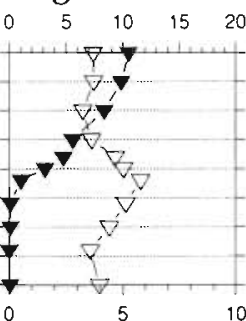

$\begin{array}{llllll}0 & 1 & 2 & 3 & 4 & 5\end{array}$

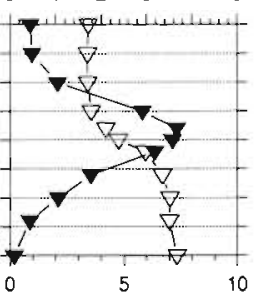

$0 \quad 500 \quad 1000 \quad 1500$

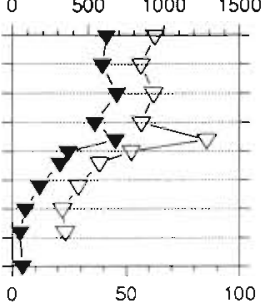

CHL Fluorescence

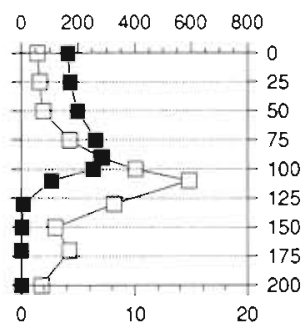

$\begin{array}{lllll}0 & 50 & 100 & 150 \quad 200\end{array}$
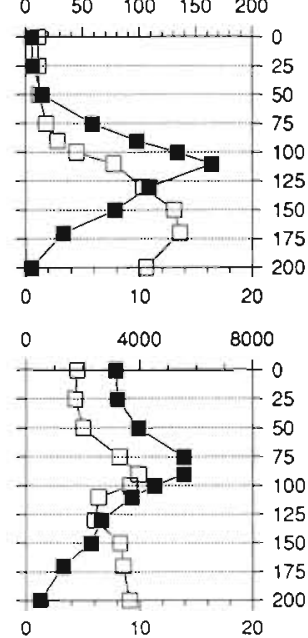

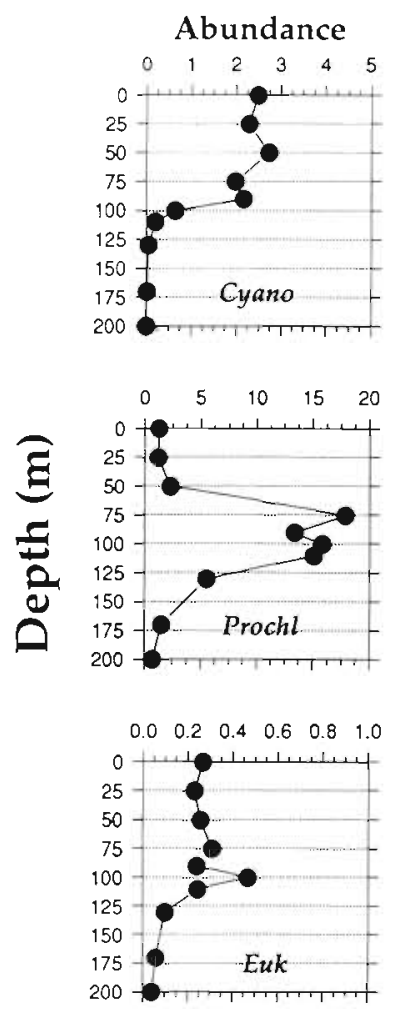

Light Scatter

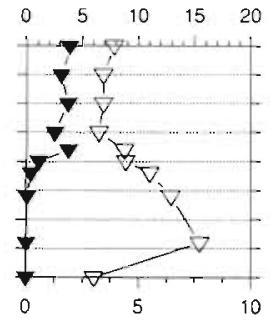

$\begin{array}{llllll}0 & 1 & 2 & 3 & 4 & 5\end{array}$
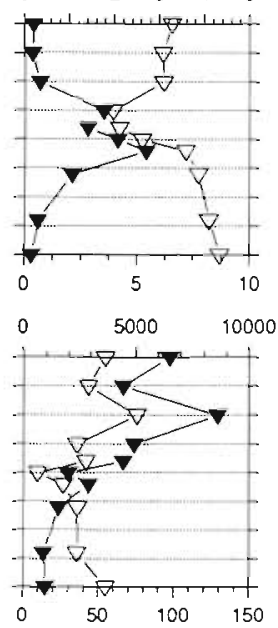

CHL Fluorescence

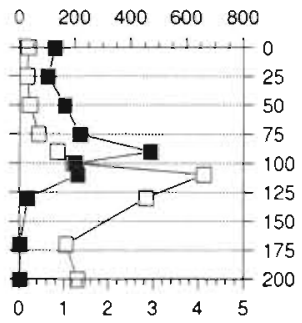

$\begin{array}{lllll}0 & 50 & 100 & 150 & 200\end{array}$

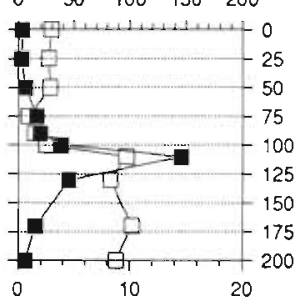

0 1000200030004000

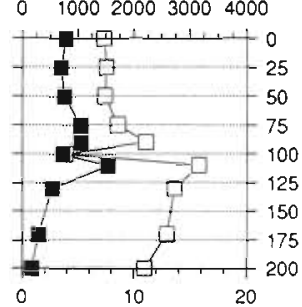

Fig. 4. Ultraphytoplankton at Stn 54. See Fig. 3 legend for description are invariably present but in smaller numbers. There is a need to reconcile this view of the phytoplankton with the more common perspective derived from bulk measures of chl a. To date, various authors have expressed flow cytometric measurements of phytoplankton in terms of 'total fluorescence' (Demers et al. 1989, Li 1989, Perry \& Porter 1989, Chisholm 1992) but only Shimada et al. (1993) have considered the relationship of this index to chl a. In this paper, we indicate explicitly how the estimates of abundance and pigment content for each cell group should be related to chl a (Eq. 1).

The recovery of bulk phytoplankton biomass on the basis of ultraphytoplankton is grounded on the following assumption: namely that there is no significant contribution to overall biomass from larger phytoplankton. Most of the chlorophyll-bearing cells in the oligotrophic waters of the eastern Mediterranean Sea are small $(<10 \mu \mathrm{m})$. We have verified this directly (Yacobi 
et al. unpubl.) and the results are consistent with the general view that in waters of low total chl a (e.g. $<1 \mu \mathrm{g} I$ $\left.{ }^{-1}\right)$, most $(>85 \%)$ of the chl $a$ is accounted for by the $<10 \mu \mathrm{m}$ fraction (Raimbault et al. 1988). This is not to say that larger cells do not occur. Indeed, many species of variouslysized phytoplankton have been observed in these waters (Kimor \& Wood 1975, Kimor et al. 1987) and macroscopic phytoplankton colonies or mats are important agents of nutrient cycling in other oceanic regions (Carpenter \& Romans 1991, Villareal et al. 1993). However, based on the inverse relationship between abundance and size of oceanic particles (e.g. Stramski \& Kiefer 1991), it is expected that cells $>10 \mu \mathrm{m}$ would generally occur at concentrations less than about 1 to 10 per ml. Thus, when the sample volume is large (e.g. 2 to $4 \mathrm{l}$ ), sufficient numbers of the larger cells are collected and the estimates of biomass approach an upper value. However, oceanographic
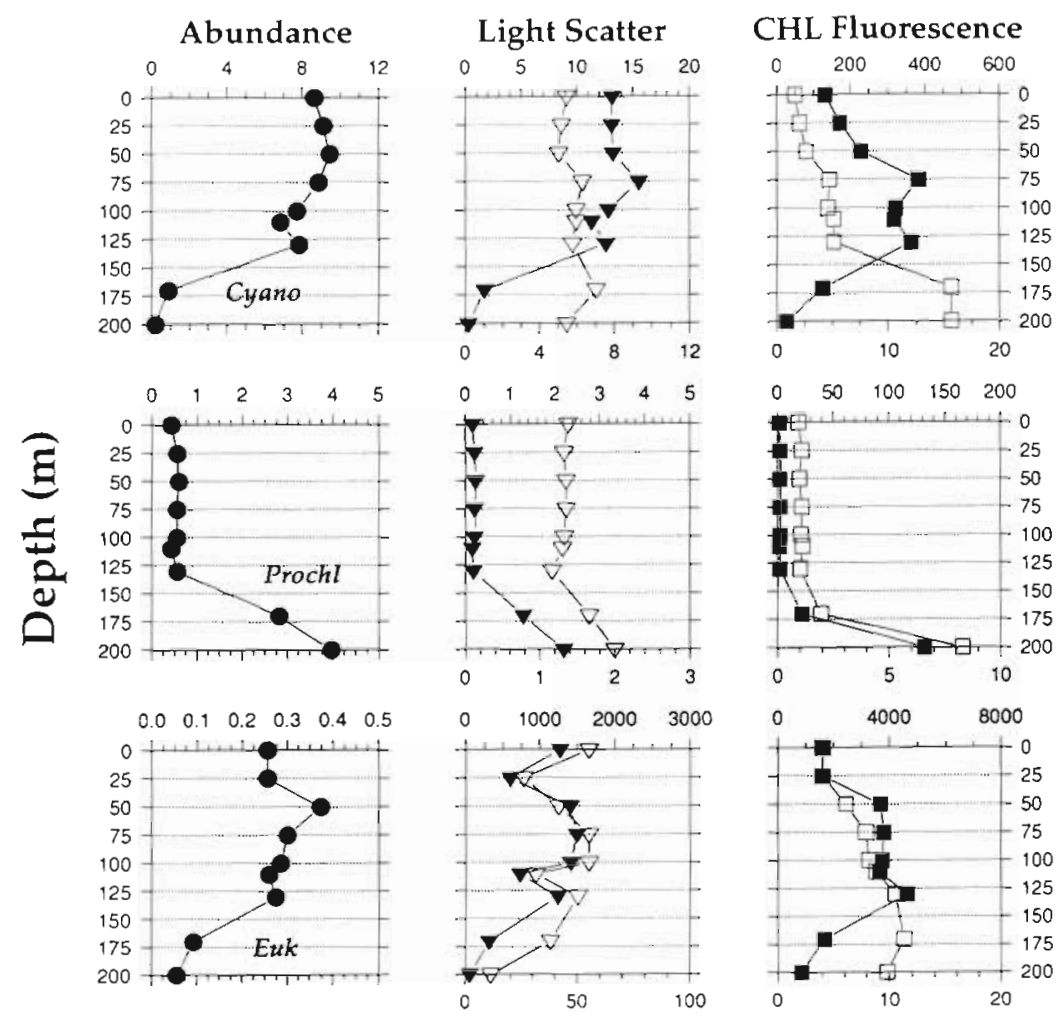

Fig. 5. Ultraphytoplankton at Stn 18. See Fig. 3 legend for description

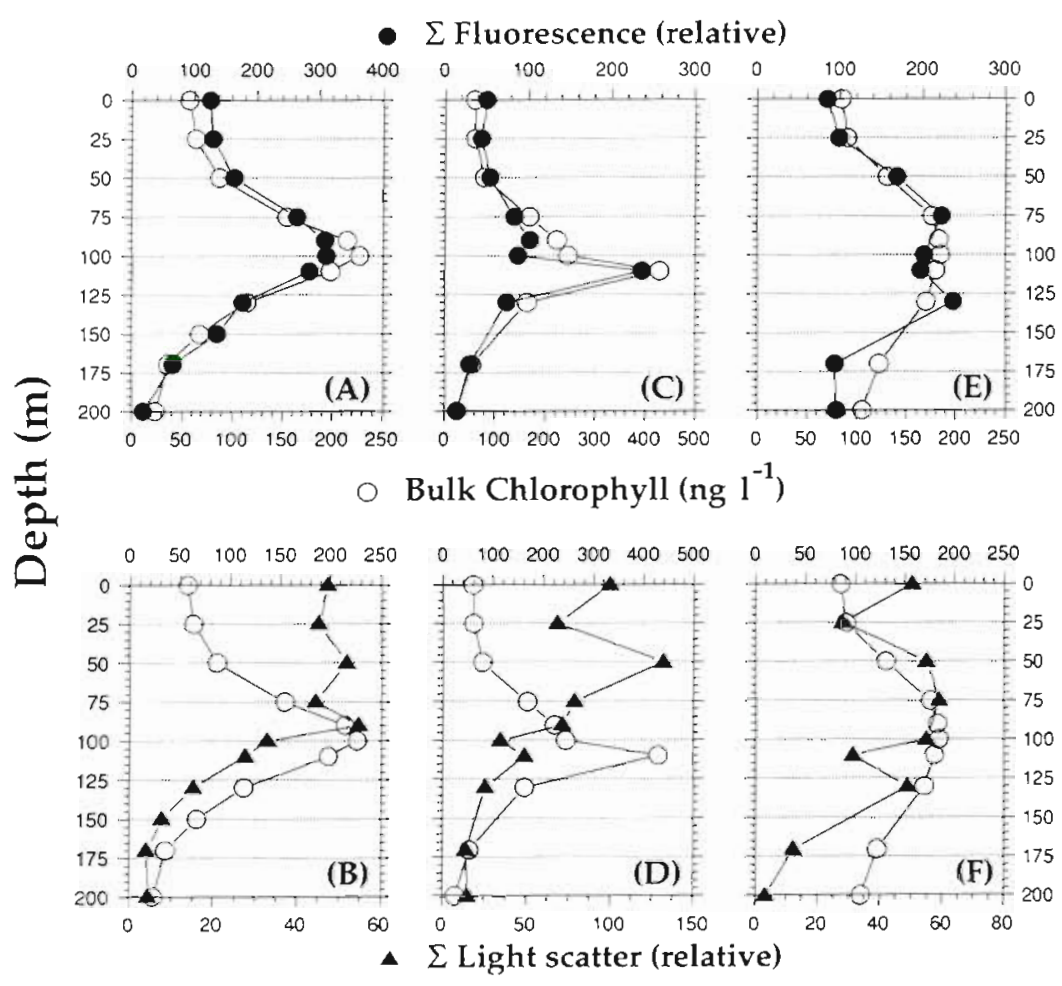

Fig. 6. Vertical distribution of $(0)$ bulk chl $a_{1}(-)$ total fluorescence, $F_{1}$ and (A) total scatter, $S$, along the horizontal transect at $(A, B) 33^{\circ} 30^{\prime} N$, (C, D) Stn 54 and $(E, F) \operatorname{Stn} 18$ estimates of chl a are commonly derived from samples of smaller volumes (100 to $1000 \mathrm{ml}$ ). Our present concern is whether bulk measures of chl a made by filtering plankton contained in $250 \mathrm{ml}$ can be represented by counts of cells contained in the $0.5 \mathrm{ml}$ samples used for flow cytometric analyses.

As described earlier, it is not possible to derive chl a from Eq. (1) and $C$ from Eq. (2): this is because $\psi_{1}$ and $\chi_{i}$ are not known. In lieu of this, we have calculated the 'total fluorescence', $F$, and the 'total scattering', $S_{i}$ which are the ratios chl $a: \Psi$ (Eq. 3b) and $C: X$ (Eq. 4 b) respectively. The result from this analysis is that the depth variation of $F$ matched that of chl a very well (Fig. 6A, C, E). Shimada et al. (1993) reported the same result for phytoplankton in the western Pacific Ocean. Possibly, the values of $\psi_{1}$ for prochlorophytes, cyanobacteria and eukaryotic ultraplankton are not very different; or there are compensatory differences amongst the 3 values. Elsewhere, we 
Fig. 7 Multiple regression fit (Eq. 5) of the chl a data at Stn 72 (top row), Stn 54 (centre row) and pooled from all stations (bottom row). Right column shows scatterplots of measured chl $a$ and fitted values of $\sum n_{1} f_{l} \psi_{l}^{\prime}$. Left column shows depth profile of $(O)$ measured $c h l a$ and $(\Delta)$ fitted values of $\sum n_{1} f_{1} \psi_{1}^{\prime}$. Centre column shows the percentage contribution to chl a from ( $\boldsymbol{\nabla})$ prochlorophytes, ( - ) cyanobacteria, and $(\bullet)$ eukaryotic ultraplankton according to Eq. (6). Estimated values for $\psi_{i}^{\prime}$ are as follows with $i=1$ for prochlorophytes, $i=2$ for cyanobacteria and $j=3$ for eukaryotes: at $\operatorname{Stn} 72, \psi_{1}^{\prime}=69, \psi_{2}^{\prime}=102$, $\psi_{3}^{\prime}=26$; at Stn $54, \psi_{1}^{\prime}=227, \psi_{2}^{\prime}=535$ $\psi_{3}^{\prime}=70$; for pooled data, $\psi_{1}^{\prime}=106$, $\psi_{2}^{\prime}=99, \psi_{3}^{\prime}=38$
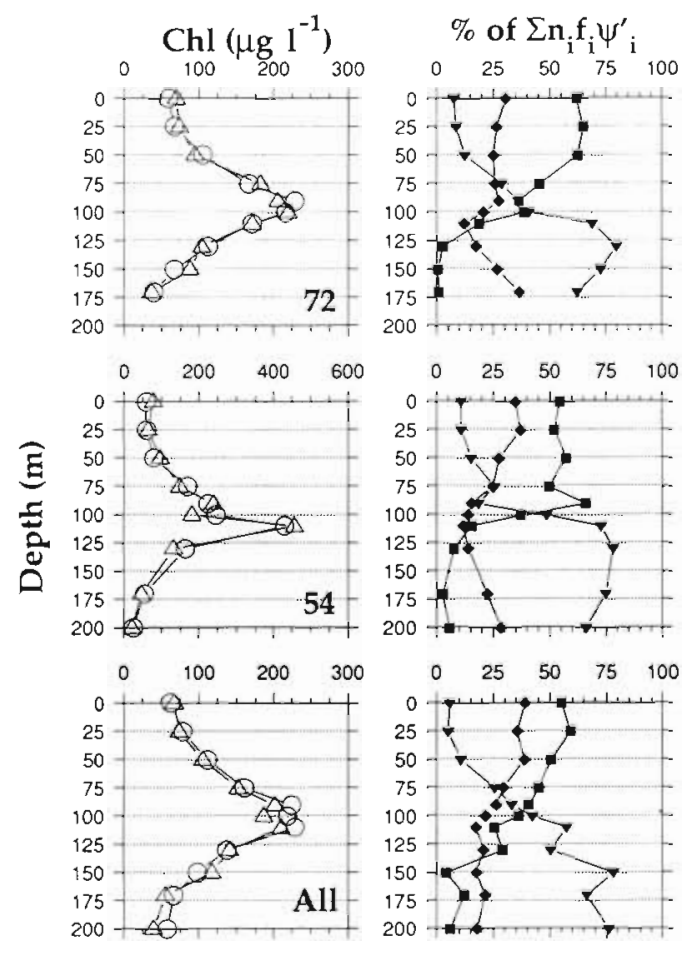
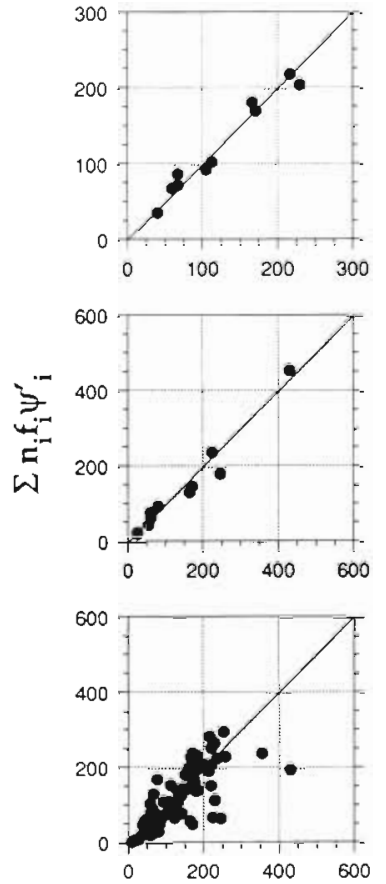

Measured $\mathrm{ChI}\left(\mu \mathrm{g} \mathrm{l}^{-1}\right)$ analysed Eq. (1) to examine the sensitivity of chl $a(z)$ to relative changes in $\psi_{i}(z)$. For phytoplankton in the oligotrophic central North Atlantic, it appeared that a very large difference in $\psi$ (ca 500 -fold) between cells with the least and most fluorescence could be tolerated without substantially altering the depth distribution of chl a (W. K. L. Li unpubl.). It is now important that the experiments of Sosik et al. (1989) on fluorescence yield of Thalassiosira weissflogii, Hymenomonas carterae and Amphidinium carteri be repeated on typical members of the prochlorophytes, cyanobacteria and eukaryotic ultraplankton.

For the sake of discussion, if we accept that a single value of $\Psi(z)$ [or $X(z)$ ] can be taken to represent all the values of $\psi_{i}(z)$ [or $\chi_{1}(z)$ ] at a given depth (Eqs. 3b \& 4 b), then the following important conclusions arise from our data. During October-November, the depth of the subsurface chl a maximum in the eastern Mediterranean was not the depth at which prochlorophytes, cyanobacteria or eukaryotic ultraplankton attained their maximum abundances. Instead it was the depth at which the combined contribution of fluorescence from all 3 groups together [i.e. $F(z)$ ] attained its maximum (Fig. 6A, C, E). We conclude that the subsurface chl a peak was not a maximum in the carbon biomass of ultraphytoplankton because the profiles of $S(z)$ were distinctly different from those of $\mathrm{chl} \mathrm{a(z)}$ (Fig. 6B, D, F). The subsurface chl a maximum was a co-manifestation of the vertical distribution of cells $\left(n_{j}\right)$ and of depth-related (adaptive) variations in cellular pigment content (indexed by $f_{i}$ ).

Earlier, Gilmartin \& Revelante (1988) similarly pointed out that in the northern Adriatic Sea, the cell concentrations of picoplankton were maximal in the surface layers and not at the depth of the subsurface chl a maximum. Further, they similarly suggested that the difference between the vertical distributions of picoplankton chlorophyll and cell concentrations were due to depth-related differences in fluorescence intensities. However, this abbreviated report contained no description of prochlorophytes nor quantitative indices of cellular pigment or carbon content.

In stable oligotrophic environments, it is characteristic for the chl a maximum to be deeper than the maximum of phytoplankton carbon biomass (Steele 1964, Cullen 1982, Longhurst \& Harrison 1989). Our results indicate that this apparently simple relationship is in fact a manifestation of the different degrees to which constituent ultraphytoplankton groups adjust their cell contents of carbon and chlorophyll. The key to delineating various possible vertical patterns is to recognise that the cell groups contribute differently to total carbon and to chlorophyll. In the eastern Mediterranean, it appears as if much of the carbon is attributable to eukaryotic ultraphytoplankton, but that chlorophyll is more evenly partitioned such that the contributions from prochlorophytes and cyanobacteria cannot be dismissed. In the tropical and subtropical western 
Pacific studied by Furuya (1990), the subsurface chI a peak was ascribable, partly to increased cellular content of chl $a$, but primarily to an increase in phytoplankton carbon biomass. In this context, a significant feature in the Pacific data was the larger mean diameter of cells comprising the chl a maximum layer.

The profiles of $s_{t}(z), n_{i}(z) \cdot s_{i}(z)$ and $S(z)$ (Figs. 3 to 6 ) are the first in which we have explicitly examined the influence of cell size variation on the vertical distribution of ultraphytoplankton biomass. In previous studies (Li et al. 1992a, 1993), we addressed this issue only partially. Cell size was measured as Coulter cell volume (FACS Analyzer flow cytometer, Becton Dickinson) but was available only for the eukaryotic ultraplankton; prochlorophytes and cyanobacteria were too small so that their signals were indistinguishable from instrument noise. In these previous studies, the carbon content of eukaryotic ultraplankton was estimated using the Strathmann (1967) formula on measured Coulter volumes; but for prochlorophytes and cyanobacteria, depth-independent values of 59 and $250 \mathrm{fg} \mathrm{C} \mathrm{cell}^{-1}$ respectively were assumed. The present results (Figs. 3 to 5) and those of others (Olson et al. 1990 a, b) clearly show depth-related variations in cellular light scatter of prochlorophytes and cyanobacteria which should not be ignored. The task remains to adopt the approach of Chisholm (1992) for converting measurements of light scatter to cellular carbon content.

The second way in which we examined our data was to assume $\psi_{i}(z)$ to be independent of depth. For each cell group $i$, a single parameter $\psi$, characterized the entire depth profile. Given the likelihood that this assumption may not be valid, this analysis must be viewed with care. Nevertheless, a cautious consideration is worthwhile because others have performed this analysis on HPLC pigment data giving interesting conclusions (Gieskes \& Kraay 1983, Gieskes et al. 1988). This partitioning of chl a to constituent groups is different from a size fractionation of chl a using membrane filters because such filters do not achieve 'clean' separation of the cell groups. For example, the filtrate from a $1 \mu \mathrm{m}$ Nuclepore membrane would contain prochlorophytes, cyanobacteria as well as small members of the eukaryotic picoplankton. Our regression analysis indicates a marked distinction between cyanobacteria and prochlorophytes, the former dominating the contribution to chl a near the surface, and the latter dominating the contribution to chl a at depth (Fig. 7). This concurs with the analysis of Gieskes (1991) for the oligotrophic Banda Sea.

In the future, when much more data are available, it may be possible to improve this regression approach by estimating $\psi_{j}(z)$ according to depth, thereby foregoing the assumption of depth-independent $\psi_{j}^{\prime}$. In other words, for data obtained from a given region amenable to characterization by a typical vertical structure and physiological parameters, it might be possible to extract, by regression, the values of $\psi_{i}(z)$ using an adequately large database of chl $\alpha(z), n_{i}(z)$ and $f_{i}(z)$. With sufficient data on HPLC pigment fingerprints, Gieskes et al. (1988) were able to apply the regression approach to algal assemblages deemed similar by cluster analysis.

In conclusion, we have confirmed the occurrence and numerical dominance of prochlorophytes, cyanobacteria and eukaryotic ultraplankton in the oligotrophic waters of the Mediterranean Sea. In these waters, it appears that the vertical distribution of chl a can be explained on the basis of the combined contribution from depth-related variations in cell abundance and relative cellular pigment content. This is a promising step towards understanding the bulk properties of phytoplankton from a study of the properties of constituent cell groups.

Acknowledgements. We thank the crews of RV 'Shikmona' and RV 'Bilim' for their help, Dr Esther Lubzens for assistance in cryopreservation of samples, and Marley Weiser for some of the chlorophyll analyses. This work was carried out as part of the LBDS03 and POEM-BC 09 multinational program. We thank the following for heading various parts of these projects: Drs Arthur Hecht, Nurit Kress, Ilkay Salihoglu and Emin Ozsoy. Financial support to A.M.W. was from ONR Project N0014-92-J-1174. This work was also supported by the Department of Fisheries and Oceans, Canada.

\section{LITERATURE CITED}

Berman, T., Townsend, D. W., El-Sayed, S. Z., Trees, C. C. Azov, Y (1984). Optical transparency, chlorophyll and primary productivity in the Eastern Mediterranean near the Israeli coast. Oceanol. Acta 7: 367-372

Carpenter, E. J., Romans, K. (1991). Major role of the cyanobacterium Trichodesmium in nutrient cycling in the North Atlantic Ocean. Science 254: 1356-1358.

Chisholm, S. W (1992). Phytoplankton size. In: Falkowski P. G., Woodhead, A. D. (eds.) Primary productivity and biogeochemical cycles in the sea. Plenum, New York, p. 213-237

Cullen, J. J. (1982). The deep chlorophyll maximum: comparing vertical profiles of chlorophyl $a$. Can. J. Fish. Aquat Sci. 39: 791-803

Demers, S., Davis, K., Cucci, T L. (1989). A flow cytometric approach to assessing the environmental and physiological status of phytoplankton. Cytometry 10:644-652

Eppley, R. W., Harrison, W. G., Chisholm, S. W., Stewart, E (1977). Particulate organic matter in surface waters off Southern California and its relationship to phytoplankton. J. mar. Res. 35: 671-696

Furuya, K. (1990). Subsurtace chlorophyll maximum in the tropical and subtropical western Pacific Ocean: vertical profiles of phytoplankton biomass and its relationship with chlorophyll $a$ and particulate organic carbon. Mar. Biol. 107: 529-539 
Gieskes, W. W. C. (1991). Algal pigment fingerprints: clue to taxon-specific abundance, productivity and degradation of phytoplankton in seas and oceans. In: Demers, S. (ed.) Particle analysis in oceanography. Springer-Verlag, Berlin, p. 61-99

Gieskes, W. W. C., Kraay, G. W. (1983). Dominance of cryptophyceae during the phytoplankton spring bloom in the central North Sea detected by HPLC analysis of pigments. Mar. Biol. 75: 179-185

Gieskes, W. W. C., Kraay, G. W., Nontji, A., Setiapermana, D., Sutomo (1988). Monsoonal alternation of a mixed and a layered structure in the phytoplankton of the euphotic zone of the Banda Sea (Indonesia): a mathematical analysis of algal pigment fingerprints. Neth. J. Sea Res. 22: $123-137$

Gilmartin, M., Revelante, N. (1988). Observations on the relative contribution of pico- and nanoplankton to the subsurface chlorophyll maximum in the Northern Adriatic Sea. Rapp. P.-v. Réun. Cons. int. Explor. Mer 31: 225

Kimor, B., Berman, T., Schneller, A. (1987). Phytoplankton assemblages in the deep chlorophyll maximum layers off the Mediterranean coast of Israel. J. Plankton Res. 9: $433-443$

Kimor, B., Wood, E. J. F. (1975). A plankton study in the eastern Mediterranean Sea. Mar. Biol. 29: 321-333

Landry, M., Kirshtein, J., Monger, B. (1993). Quantitative enumeration of paraformaldehyde preserved Prochlorococcus by flow cytometry. Signal \& Noise $6: 3$

Li, W. K. W. (1989). Shipboard analytical flow cytometry of oceanic ultraphytoplankton. Cytometry 10:564-579

Li, W. K. W., Dickie, P. M., Harrison, W. G., Irwin, B. D. (1993). Biomass and production of bacteria and phytoplankton during the spring bloom in the western North Atlantic Ocean. Deep Sea Res. II 40: 307-327.

Li, W. K. W., Dickie, P. M., Irwin, B. D., Wood, A. M. (1992a) Biomass of bacteria, cyanobacteria, prochlorophytes and photosynthetic eukaryotes in the Sargasso Sea. Deep Sea Res. 39: 501-519

Li, W. K. W., Lewis, M. R., Lister, A. (1992b). Flow cytometric detection of prochlorophytes and cyanobacteria in the Gulf of Policastro, Italy. Arch. Hydrobiol. 124: 309-316

Li, W. K. W., Wood, A. M. (1988). Vertical distribution of North Atlantic ultraphytoplankton: analysis by flow cytometry and epifluorescence microscopy. Deep Sea Res. 35: $1615-1638$

Longhurst, A. R., Harrison, W. G. (1989). The biological pump: profiles of plankton production and consumption in the upper ocean. Prog. Oceanogr. 22: 47-123

Monger, B. C., Landry, M. R. (1993). Flow cytometric analysis of marine bacteria with Hoechst 33342. Appl environ. Microbiol. 59: 905-911.

Olson, R. J., Chisholm, S. W., Zettler, E. R., Altabet, M. A., Dusenberry, J. A. (1990a). Spatial and temporal distributions of prochlorophyte picoplankton in the North Atlantic Ocean. Deep Sea Res. 37: 1033-1051

Olson, R. J., Chisholm, S. W., Zettler, E. R., Armbrust, E. V. (1990b). Pigments, size, and distribution of Synechococcus

This article was submitted to the editor in the North Atlantic and Pacific Oceans Limnol Oceanogr. 35: 45-58

Olson, R. J., Zettler, E. R., Anderson, O. K. (1989). Discrimination of eukaryotic phytoplankton cell types from light scatter and autofluorescence properties measured by flow cytometry. Cytometry 10: 636-643

Perry, M. J., Porter, S. M. (1989). Determination of the crosssection absorption coefficient of individual phytoplankton cells by analytical flow cytometry. Limnol. Oceanogr. 34 : $1727-1738$

Platt, T (1989). Flow cytometry in oceanography. Cytometry 10: 500

Raimbault, P., Rodier, M., Taupier-Letage, I. (1988). Size fraction of phytoplankton in the Ligurian Sea and the Algerian Basin (Mediterranean Sea): size distribution versus total concentration. Mar. microb. Fd Webs 3: 1-7

Shimada, A., Hasegawa, T. Umeda, I., Kadoya, N., Maruyama, T (1993). Spatial mesoscale patterns of West Pacific picophytoplankton as analyzed by flow cytometry: their contribution to subsurface chlorophyll maxima. Mar. Biol. 115: 209-215

Sieracki, M. E., Cucci, T. L. (1993). A note on losses of Prochlorococcus cells due to preservation. Signal \& Noise $6: 2$

Sosik, H. M., Chisholm, S. W., Olson, R. J. (1989). Chlorophyll fluorescence from single cells: interpretation of flow cytometric signals. Limnol. Oceanogr. 34: 1749-1761

Steele, J. H. (1964). A study of production in the Gulf of Mexico. J. mar. Res. 3: 211-222

Stramski, D., Kiefer, D. A. (1991). Light scattering by microorganisms in the open ocean. Prog. Oceanogr. 28: 343-383

Strathmann, R. R. (1967). Estimating the organic carbon content of phytoplankton from cell volume or plasma volume. Limnol. Oceanogr. 12:411-418

Vaulot, D., Courties, C., Partensky, F. (1989). A simple method to preserve oceanic phytoplankton for flow cytometric analyses. Cytometry 10: 629-635

Vaulot, D., Partensky, F., Neveux, J., Mantoura, R. F. C., Llewellyn, C. A. (1990). Winter presence of prochlorophytes in surface waters of the northwestern Mediterranean Sea. Limnol. Oceanogr. 35: 1156-1164

Vaulot, D., Partensky, F. (1992). Cell cycle distributions of prochlorophytes in the north western Mediterranean Sea. Deep Sea Res. 39: 727-742

Veldhuis, M. J. W., Kraay, G. W. Gieskes, W. W. C. (1993) Growth and fluorescence characteristics of ultraplankton on a north-south transect in the eastern North Atlantic. Deep Sea Res. Il 40: 609-626

Villareal, T. A., Altabet, M. A., Culver-Rymsza, K. (1993). Nitrogen transport by vertically migrating diatom mats in the North Pacific Ocean. Nature 363: 709-712

Yentsch, C. M., Campbell, J. W. (1991). Phytoplankton growth: perspectives gained from flow cytometry. J. Plankton Res. 13 Supplement: 83-108

Zaika, V. E., Yashin, V A. (1984). Luminescing picosuspension $(0.2-2.0 \mu \mathrm{m})$ in oligotrophic waters of the Mediterranean and Black Seas. Dokl. Biol. Sci. 275: 262-264

Manuscript first received: May 17, 1993

Revised version accepted: August 23, 1993 